\title{
Is Judicial Review a Cure for Bigness?
}

Closing a chapter on the judicial review of EU competition law decisions should be an easy task for a lawyer trained in ECHR matters. The case-law of the ECtHR described in this book suggests that the system of competition law enforcement in the EU does not comply with the requirements of the right to a fair trial as guaranteed by Article 6(1) ECHR. The system of EU competition law enforcement is based on the exercise of administrative discretion as policing powers (Section 8.4.). The EU Commission investigates and prosecutes, opens investigations, searches premises and fines undertakings (Chapters 10 and 11). Such proceedings are considered to be criminal in nature by the ECtHR, irrespective of their domestic qualification (Section 5.3.4.). The judicial review required by Article 6(1) ECHR in such cases should involve a full review of the decision concerned and the power to quash in all respects the disputed administrative decision (Chapters 14 and 15).

These safeguards are not met in EU competition law. The judicial review performed by the EU Courts cannot correct the structural lack of independence of the EU Commission. Moreover, the review of legality combined with the full review of fines cannot lead to a competition law decision adopted by the EU Commission being declared void in full, decided de novo by the EU Courts or sent for re-consideration (Chapter 16). Hence, the judicial review of competition law decisions in the EU does not comply with Article 6(1) ECHR.

This conclusion might be valuable in itself, especially in relation to the Treaty-based rules of interpretation of the Charter that establish a link of equivalence between the ECHR, the interpretation of the ECHR by the ECtHR and the provisions of the Charter. This conclusion will be of particular importance if the EU will conclude its accession to the ECHR.

At this point, however, it remains important to understand the reasons that could be grounding the EU Courts' preference for deferential judicial review despite the fact that it is highly contested by practitioners and academics. Such a pursuit is important for a few reasons. First, despite the growing investigative powers of the EU Commission and the growing amounts of fines imposed for breaches of EU competition law, there is little evidence that cartels are disappearing or that the dominant firms are abusing less their dominant positions. On the contrary, it appears that the movement toward 
concentration of economic power is becoming more obvious and more serious. ${ }^{1}$

The second reason to understand the defence of the current system of EU competition law enforcement by the EU Courts is linked to the litigation of such cases. The increased use of commitment and settlement proceedings suggests that undertakings prefer to negotiate and to close competition cases as soon as possible. Some authors have voiced concerns that this would lead to a worrying decrease in court proceedings in EU competition law. ${ }^{2}$ These concerns have not been validated. Despite the litigation costs involved, undertakings continue to bring actions against the decisions of the EU Commission and to challenge the Commission's assessments, its independence and the deferential judicial review performed by the EU Courts. In other words, even if the undertakings concerned know that they have little chance to overturn the EU Commission's decisions, they continue to attempt to do so.

Lastly, calls from within the EU adjudicatory establishment indicate a desire to reconceive judicial review in the EU. Thus, Prek and Lefèvre - judge and legal secretary at the GC respectively - acknowledged that the judicial review practiced by the EU Courts should be calibrated according to the type of administrative discretion deployed by the EU Commission. ${ }^{3}$ Prek and Lefèvre distinguish between, first, the "power of appraisal" or "discretion proper" when "a rule is intended to delegate to the administration a freedom to decide between different equally lawful course of action". EU Commission exercises "discretion proper" in competition law when it initiates or closes infringement proceedings. In light of the permissive language, the judicial review performed by the CJEU in such cases should be more limited. At the same time, judicial review should take into account the "legal context to which the provision in question belongs". ${ }^{4}$

Second, they note that the EU Commission benefits from a "margin of appraisal" when assessing whether a rule is applicable. However, they argue that neither the interpretation of the law, nor the establishment of facts are source of administrative discretion. On contrary,

1 Wu, op. cit.

2 Barbier de la Serre, Eric. "Competition Law Cases before the EU Courts: Is the Well Running Dry." The Role of the Court of Justice of the European Union in Competition Law Cases. Eds. Massimo Merola and Jacques Derennes. Bruxelles: Bruylant, 2012, pp. 87-100.

3 Prek, Miro and Silvère Lefèvre. “'Administrative Discretion', 'Power of Appraisal' and 'Margin of Appraisal' in Judicial Review Proceedings Before the General Court." Common Market Law Review 56 (2019): pp. 339-380.

4 Prek and Lefèvre (2019), op. cit., p. $35^{2}$. 
under Article $19 \mathrm{TEU}$, the ECJ must ensure that in the interpretation and application of the Treaties the law is observed. Thus, providing a meaning to the legislation is a task entrusted to the EU Courts and not to the administration. The General Court is therefore duty-bound to carry out a thorough review of the interpretation favoured by the administration and, if it disagrees, to substitute its interpretation for that of the administration. ${ }^{5}$

Finally, Prek and Lefèvre acknowledge that the administration may enjoy a margin of discretion when conducting legal appraisal of facts, that is confronting the factual basis of a case with its statutory basis. ${ }^{6}$

In the sections below I propose to comprehend deferential judicial review from novel perspectives. For this purpose, I attempt to solve the conundrum posed to adjudication by economic and technical evidence, by the ethos surrounding the role of the administration, by bias and monoculture and by problems of organized complexity.

\subsection{Adjudication and Economic Evidence}

Vos has shown that "decision-makers often act in the face of scientific uncertainty and complex technical issues regarding matters ranging from competition law to environmental protection or food safety". ${ }^{7}$ Vos has also suggested that in some areas, such as agriculture, environment and pharma, the EU courts have abandoned their deferential standard of review in favour of a more activist stance. ${ }^{8}$ In the field of EU competition law, however, the EU courts continue to employ judicial restraint and deferral to the EU Commission's margin of discretion.

As shown above, the CJEU limits its power of review in cases that present complex economic appraisals made by the EU Commission. In these instances, the CJEU will confine its review to verifying whether the procedural rules have been respected, whether the facts have been correctly stated and

5 Prek and Lefèvre (2019), op. cit., p. 355-356.

6 Prek and Lefèvre (2019), op. cit., p. 357.

7 Vos, Ellen. "The European Court of Justice in the face of scientific uncertainty and complexity." Judicial Activism at the European Court of Justice. Eds. Mark Dawson, Bruno De Witte and Elise Muir. Cheltenham: Edward Elgar, 2013, p. 142.

8 Vos, op. cit., pp. 145-160. 
whether there has been any manifest error of appraisal or misuse of powers. 9 The accompanying reasoning offered by the CJEU is that the EU Commission enjoys a wide margin of appreciation when dealing with complex economic or technical matters.

Ibáñez Colomo has argued that the scope of the notion "complex economic assessments" over which the EU Commission enjoys a margin of appreciation remains "relatively obscure". ${ }^{10}$ Furthermore, he highlighted that "if one examines carefully the behaviour of the EU courts, it appears not only that they are less likely to be deferential to the Commission where the analysis of the authority contradicts mainstream economic principles, but that consensus positions have been relied upon to define the substantive boundaries of administrative action". ${ }^{11}$ In other words, the EU Courts defer not to the EU Commission as an agency, but to the mainstream economic consensus.

There are at least two arguments, however, that challenge the EU Courts' self-limitation for judicial review. First, the EU Treaties do not treat economic evidence, or any other type of expert evidence for that matter, as a superior or privileged category of evidence. Nor do the EU Treaties speak about the privileged margin of appreciation that the EU Commission has when performing economic assessments. Therefore, when the EU Courts limit their powers of review on the ground of the special place occupied by economic evidence or the EU Commission's wide margin of appreciation to assess it, the EU Courts appear to be interfering with the constitutional hierarchy established by EU Treaties. In fact, it could be argued that deference to the EU Commission's appraisals of economic evidence affects the separation of powers within the Union.

There is a second reason why limiting judicial review because of the economic assessments prepared by the EU Commission is problematic, this second reason is supplied from within the corps of economists themselves. In fact, when policy-makers and courts - domestic or international - assess economic evidence, they tend to treat it as if it was scientific evidence, subject to consensus. However, economists themselves are contesting the strong reliance of policy-makers on economic evidence.

Keynes and Hayek were two of the most important economic theorists of the last century. It is important to note that, despite the fact that they belong

9 See, between many, T-109/o2, T-118/o2, T-122/o2, T-125/o2, T-126/o2, T-128/o2, T-129/o2, T132/o2 and T-136/o2 (joined cases), BollorésA and Othersv.Commission, ECLI:EU:T:2007:115, paragraph 664 .

10 Ibáñez Colomo, op. cit., p. 719.

11 Ibáñez Colomo, op. cit., p. 720. 
to the opposite sides of the political spectrum, they were both concerned with the growing authority of economics over other social fields.

John Maynard Keynes was probably the first to argue against the growing influence of economics, by highlighting that "the ideas of economists and political philosophers, both when they are right and when they are wrong, are more powerful than what is commonly understood. Indeed, the world is ruled by little else". ${ }^{2}$

The Nobel Memorial Prize in Economic Sciences has been introduced in 1968, following the successful lobbying and financing by Sweden's central bank, Sveriges Riksbank. Friedrich August von Hayek was awarded the Nobel Memorial Prize in Economic Sciences in 1974. The speech Hayek offered at the Nobel Banquet starts by acknowledging that if he had been consulted whether to establish a Nobel Memorial Prize in economics, he would "have decidedly advised against it". ${ }^{13}$ Hayek offers two compelling reasons for his attitude. First, he highlights that a Nobel Prize in Economic Sciences "would tend to accentuate the swings of scientific fashion". The second reason merits to be quoted in full because it is directly relevant to the topic of this book. Hayek declared that:

the Nobel Prize confers on an individual an authority which in economics no man ought to possess. This does not matter in the natural sciences. Here the influence exercised by an individual is chiefly an influence on his fellow experts; and they will soon cut him down to size if he exceeds his competence. But the influence of the economists that matters is an influence over laymen: politicians, journalists, civil servants and the public generally. There is no reason why a man who has made a distinctive contribution to economic science should be omnicompetent on all problems of society - as the press tends to treat him till in the end he may himself be persuaded to believe. One is even made to feel it a public duty to pronounce on problems to which one may not have devoted special attention. ${ }^{14}$ (emphasis added)

This speech Hayek offered in 1974 was not an expression of humility, he was speaking from personal experience. Offer and Söderberg showed that Hayek,

12 Keynes, John Maynard. The General Theory of Employment, Interest and Money. London: Macmillan, 1961, p. 383 .

13 Von Hayek, Friedrich August. Banquet Speech. 10 Dec 1974. Nobel Media AB 2019. Available at https://www.nobelprize.org/prizes/economic-sciences/1974/hayek/speech/ accessed on 23 February 2021.

Von Hayek, quoted above. 
with the support of American business foundations, initiated the Mont Pélerin Society in 1947. The Mont Pélerin Society gathered economists, journalists and businessmen and became "the intellectual focus of resistance to Social Democracy". ${ }^{15}$ Eight of the members of the Mont Pélerin Society went on to win the Nobel Prizes in Economic Sciences.

As Milton Friedman later wrote about his activity as a member of the Mont Pélerin Society, "the threat to a free society that we envisaged at the founding meeting of the Mont Pélerin Society is very different from the threat to a free society that has developed over the intervening period. Our initial fear was of central planning and extensive nationalization. The developing threat has been via the welfare state and redistribution". 16

Thaler, another winner of the Nobel Memorial Prize in Economic Sciences wrote in an influential work that economics was the most powerful of the social sciences. ${ }^{17}$ First, he argued that "of all the social scientists, economists carry the most sway when it comes to influencing public policy. In fact, they hold a virtual monopoly on giving policy advice". ${ }^{18}$ Second, Thaler showed that economics was the most powerful of the social sciences in an intellectual sense: "that power derives from the fact that economics has a unified, core theory from which nearly everything else follows". The basic premise of the economic theory is that people choose by optimizing and that such choices are unbiased.

The problem is, however, that neither people, nor markets appear to behave as described in the models proposed by economic theory. Raworth wrote in the opening of her book Doughnut Economics that "economics is broken. It has failed to predict, let alone, prevent, financial crises that have shaken the foundations of our society. Its outdated theories have permitted a world in which extreme poverty persists (...). And its blind spots have led to policies that are degrading the living world on a scale that threatens all of our futures".19

Raworth criticises the fact that economic theory taught in universities around the world, Econ 101, is a textbook written after wwII. She shows

15 Offer, Avner, and Gabriel Söderberg. The Nobel Factor: The Prize in Economics, Social Democracy, and the Market Turn (1st ed.). Princeton: Princeton University Press, 2016, p. 9.

16 Friedman to Max Hartwell,10 July 1985. Hoover Institution, Friedman Papers, pp. 200-210.

17 Thaler, Richard H. Misbehaving: The Making of Behavioral Economics. New York: W. W. Norton \& Company, 2016.

18 Thaler, op. cit., p. 5 .

19 Raworth, Kate. Doughnut Economics: Seven Ways to Think Like a 21st-Century Economist. Vermont: Chelsea Green Publishing, 2017, p. 3. 
that the "citizens of 2050 are being taught an economic mindset that is rooted in the textbooks of 1950, which in turn are rooted in the theories of $1850^{\prime \prime} .20$

Finally, in The Economists Hour: How the False Prophets of Free Markets Fractured Our Societies, Appelbaum offered numerous examples of policy work that resulted in market failures or crashes despite sober economic assessments. ${ }^{21}$

The practitioners involved with EU competition law have been concerned with the growing importance of economic evidence in competition law as well. They acknowledge this to be a form of "economic imperialism over other social sciences". 22 The same authors note that "under the legitimate aim of avoiding excessive formalism in the formulation and application of legal principles, economists have conquered competition law. In a way, this is perhaps fair since we jurists have failed to adequately defend the virtues of keeping competition law as a legal construct". ${ }^{23}$

Bishop, instead, highlights that within a competition law case, economic analysis cannot be disentangled from the legal analysis provided. This implies that the answer to a competition law case "is usually not to be found in the pages of academic journals but rather in close examination of the observed market data; in other words, in a close examination of the market or the economic evidence". ${ }^{24}$

Bishop highlights - unwillingly - the contradiction that is at the core of the debate described in this section. On the one hand, economic evidence is simply expert evidence which can be regularly sought in court proceedings. From this point of view, economic evidence should not be distinguished from medical or forensic evidence submitted during court proceedings. On the other hand, he acknowledges that "one can always find an economist to support any position". In addition, "the fact that expert evidence necessarily reflects the

20 Raworth, op. cit., p. 21.

21 Appelbaum, Binyamin. The Economists' Hour: False Prophets, Free Markets, and the Fracture of Society. New York: Little, Brown and Company, 2019.

22 Blanco, Luis Ortiz, and Alfonso Lamadrid de Pablo. "Expert Economic Evidence and Effects-Based Assessments in Competition Law Cases." The Role of the Court of Justice of the European Union in Competition Law Cases. Eds. Massimo Merola and Jacques Derennes. Bruxelles: Bruylant, 2012, pp. 305-312, p. 308.

23 Blanco and Lamadrid de Pablo, op. cit.

24 Bishop, Simon. "Expert Economic Evidence in European Competition Law Cases: Some Personal Views." The Role of the Court of Justice of the European Union in Competition Law Cases. Eds. Massimo Merola and Jacques Derennes. Bruxelles: Bruylant, 2012, pp. 294-304, p. 298. 
expert's opinion doesn't render the evidence of little or no value, at least not in principle". ${ }^{25}$ What is more, Bishop writes that "those familiar with economic theory will know that a large number of results can be reversed by making an alternative assumption. This is particularly true of modern economic analysis which employs game theoretic methodology". ${ }^{26}$

Bishop concludes that economic evidence should be treated in the same way as other expert evidence and be subjected to cross-examination at the earliest stages of competition law proceedings. In practice, though, there is an extremely limited scrutiny of economic evidence within the EU Commission and, in addition, this scrutiny remains internal. ${ }^{27}$

Kaupa goes a step forward in proposing that the EU Courts might be suffering from a neoliberal bias. ${ }^{28}$ This bias was made obvious in the Viking and Laval cases. ${ }^{29} \mathrm{He}$ noted that the EU courts may have fallen victim to a "conventional wisdom trap" in which "the arguments of the economic mainstream are assumed also to represent a neutral position". ${ }^{30}$

Kaupa shows that

this is a fallacious belief: not only is the economic mainstream divided in terms of economic theory (...). Economic knowledge also cannot simply be transferred into the legal discourse without losing most of its validity. The arguments of economists may sometimes boil down to simple rules, but they are based on a complex set of assumptions and preconditions (...). Legal scholars and practitioners, however, cannot possibly operate these complex economic apparatuses. Instead, they employ radically simplified versions of economic positions, which are no longer valid in a scientific sense. ${ }^{31}$

25 Bishop, op. cit., p. 300.

26 Bishop, op. cit., p. 294.

27 Bishop, op. cit., pp. 300-301.

28 Kaupa, Clemens. "Maybe not Activist Enough? On the Court's Alleged Neoliberal Bias in its Recent Labor Cases." Judicial Activism at the European Court of Justice. Eds. Mark Dawson, Bruno de Witte and Elise Muir. Cheltenham: Edward Elgar, 2013, pp. 56-75.

29 C-438/05, International Transport Workers' Federation and Finnish Seamen's Union v Viking Line ABP and OÜ Viking Line Eesti, ECLI:EU:C:2007:772. C-341/o5, Laval un Partneri Ltd $v$ Svenska Byggnadsarbetareförbundet, Svenska Byggnadsarbetareförbundets avdelning 1, Byggettan and Svenska Elektrikerförbundet, ECLI:EU:C:2007:809.

$30 \quad$ Kaupa, op. cit., p. 68.

$31 \quad$ Kaupa, op. cit. 
The following quote offers a good way to close this section and a description of the compromise needed to embrace economics in competition law without defeating all the other surrounding issues:

the influence of economics is at odds with its shortcomings as a philosophy, as a scientific doctrine, and as a set of policy norms. The invisible hand is magical thinking, and its repeated disconfirmation has had little effect. On the other hand, economics has a set of empirical disciplines and achievements, with enclaves of technical and even scientific credibility. This suggests some downgrading of authority, but not all the way. Economics is not superior to other sources of authority, but is not necessarily inferior to them either; it should be taken as one voice among many. ${ }^{32}$

\subsection{Adjudication and the Administrative Man}

Political scientists like Herbert A. Simon have contested the omnipotence of economic thought, understood as monopole of rationality, within the theory of administration. His ideas remain relevant today.

Simon highlighted that social sciences suffer from

a case of acute schizophrenia in their treatment of rationality. At one extreme, we have the economists, who attribute to economic man a preposterously omniscient rationality. Economic man has a complete and consistent system of preferences that allows him always to choose among the alternatives open to him; he is always completely aware of what these alternatives are; there are no limits on the complexity of computations he can perform in order to determine which alternatives are the best; probability calculations are neither frightening nor mysterious to him. At the other extreme, we have those tendencies in social psychology traceable to Freud that try to reduce all cognition to affect. ${ }^{33}$ (emphasis added)

Simon notes, however, that the rationality exhibited in an organization "has none of the global omniscience that is attributed to economic man". ${ }^{34} \mathrm{He}$

\footnotetext{
32 Offer and Söderberg, op. cit., p. 15.

33 Simon, op. cit., p. xxiii.

34 Simon, op. cit., p. xxiv.
} 
makes therefore the classical distinction between the economic man, always maximizing and presumed to be in charge of organisational decisions, and the administrative man, only satisficing instead of maximising and having the actual control of an organisation. For Simon, the economic man can deal with the real world and all its complexity. The administrative man, on the other hand, because of his focus on efficiency, perceives only a simplified model of the real world and "makes his choices using a simple picture of the situation that takes into account just a few of the factors that he regards as most relevant and crucial". ${ }^{35}$ Two consequences result from this limited perception of the world. First, the administrative man takes decisions without having considered all the available alternatives. Second, the administrative man "is able to make his decisions with relatively simple rules of thumb that do not make impossible demands upon its capacity for thought". ${ }^{36}$

In one instance, the administrative man is equal in his decision-making powers to the economic man, more precisely in the pursuit of the principle of efficiency:

the theory of administration is concerned with how an organisation should be constructed and operated in order to accomplish its work efficiently. A fundamental right of administration, which follows almost immediately from the rational character of 'good' administration, is that among several alternatives involving the same expenditure the one should be selected which leads to the greatest accomplishment of administrative objectives; and among several alternatives that lead to the same accomplishment the one should be selected which involves the least expenditure. Since this principle of efficiency is characteristic of any activity that attempts rationally to maximize the attainment of certain ends with the use of scarce means, it is characteristic of economic theory as it is of administrative theory. ${ }^{37}$

In a supranational setting like the EU every interaction between the administrative and the judicial branch is meaningful. Conflict between branches of government can be detrimental to integration pursuits. This is obvious from a survey of the literature that questions the shape of the separation of powers in the EU. Conway wrote that "the EU clearly does not represent a pure expression of the tripartite separation of powers between legislative, executive and

\footnotetext{
35 Simon, op. cit., p. xxv.

36 Simon, op. cit., p. xxvi.

37 Simon, op. cit., p. 39.
} 
judicial branches" and that "the main way in which the EU departs from the tripartite conception of a separation of powers is the role of the Court itself". 38 Höreth, on the other hand, has argued that the EU "has not only the most formalized and complex set of decision-making rules of any political system of the world but also a unique system of checks and balances". 39

The interesting question to ask within the context of the existing checks and balances within the EU is the extent to which the three branches of government in an incomplete supranational integration project owe each other loyalty and support.

The work of Simon highlights the primordial place occupied by the administration in modern societies and the attempt to equate rationality and rational choice with the administrative exercise of power. In this model of the administration, facts become evidence and the administrators translate reality into decisions maximizing the image and power of the administration. If courts were to challenge frequently these decisions, they might be appearing as challenging the principle of rationality itself. Consequently, if courts were to contest frequently the rationality of the decisions reached by the administration, this might lead to the withering of trust in the administration. In turn, defence of trust in the administration is important not only for the swift democratic processes in a political system, but also for the healthy functioning of the courts themselves. In fact, a lack of trust in the administration might lead to a higher number of administrative decisions being contested. Individuals might seek a defence of the principle of rationality in a court instead of in the administrative agency charged with the matter. The courts' agendas could thus be significantly affected.

Courts must therefore strike a gentle balance when performing judicial review between the need to preserve the exercise of the principle of rationality by the administration and the need to preserve a manageable size of applications against the administration. Deference meets both these needs: on the one hand, by deferring to the decision of the administration, the courts strengthen the image of the administration being a specialist in a certain field. This can also empower the administration to build technical expertise in the field deferred to it. On the other hand, deference can limit the number of

38 Conway, op. cit., p. 200.

39 Höreth, Marcus. "The least Dangerous Branch of European Governance? The European Court of Justice Under the Checks and Balances Doctrine." Judicial Activism at the European Court of Justice. Eds. Mark Dawson, Bruno de Witte and Elise Muir. Cheltenham: Edward Elgar, 2013, pp. 32-55, p. 5 o. 
applications being lodged with a court because of the applicants' knowledge that courts will defer.

In the field of EU competition law, the EU Commission seeks to represent the economic man that Simon described. As I have suggested in Part 3 of this work, DG COMP employs a method of investigation based on fact finding and economic theory. Competition law investigations last for many years and involve vital EU Commission resources. Cases are carefully selected by the EU Commission because "policy is often formulated through the choice of individual cases and thus by establishing that a given line of conduct is in breach of a legal provision". ${ }^{40}$ Questioning the EU Commission's competition law decisions through constant judicial review would amount to questioning the principle of rationality that the EU Commission is called to embody. Moreover, this would imply sanctioning a way of functioning and policy-making that is considered very successful. If such sanctioning were to happen often, serious questions would arise about the competence of the EU Commission in competition law matters and about the efficiency of the EU Commission's administrative action. This is especially true in light of the fact that only a handful of competition decisions are issued yearly.

To conclude, the deferential judicial review practiced by the EU courts in competition law might be deemed to be necessary for the preservation of efficient administrative action and of the image of the economic man that the EU Commission embodies.

\subsection{Adjudication, Bias and Monoculture}

A recent trend in social sciences describes the interest psychologists have shown for adjudication and the interest that adjudicators have shown for work on cognitive bias. Sood writes that "there has been a burgeoning of interdisciplinary scholars who are combining tools of psychology and legal scholarship to ask new questions about the law". ${ }^{41}$ Sood's academic work has been focused on a bias called motivated cognition, which is "a human tendency to reason toward preferred outcomes by perceiving, interpreting, or evaluating information in a biased manner, without realizing one is doing so". 42

\footnotetext{
$40 \quad$ Ibáñez Colomo, op. cit., p. 187.

41 Sood, Avani Mehta. "Applying Empirical Psychology to Inform Courtroom Adjudication Potential Contributions and Challenges." Harvard Law Review Forum 130.301 (2017). 
The research on cognitive bias affecting adjudication is in its incipient phase. However, it can be suspected that cognitive bias that affects the general population also affects adjudicators. Bias in favour of jurisprudential status quo or against it could be at work in the minds of legal professionals and the general public.

On the one hand, there might be a bias in favour of judicial activism. Lawyers and the public at large might prefer a judicial branch that is active. Those affected by this bias might be convinced that judicial restraint is bad for democracy at all times.

On the other hand, a version of the progress fallacy might affect the interpretation of fundamental rights. Those holding this bias might be convinced that the interpretation of fundamental rights should always expand, that stagnation or shrinking in rights interpretation negatively affects democracy.

On the opposite side of the spectrum, individuals who favour the maintenance of the current system of judicial review might be victims of the big on big bias. Big on big describes the preference for large, powerful institutions as a necessary evil to address the most important problems in the society, such as big companies. With this belief in mind, fighting cartels, for example, is only possible by a large, commanding administrative agency.

A more powerful and pervasive bias is provided by what Michaels calls monoculture. ${ }^{43}$ Combining research from economics, anthropology, ethics and psychology, Michaels suggests that "the governing pattern that a culture obeys is a master story - one narrative in society that takes over the others, shrinking diversity and forming a monoculture". 44

In the seventeenth century a religious monoculture was replaced by a scientific monoculture during which "life was understood as a series of questions with knowable answers, and the world became methodical and precise". 45 Michaels argues that the master story that has succeeded the scientific monoculture is the economic monoculture. Although money plays an important role in the economic monoculture, Michaels argues that "the economic story represents a much more nuanced and insidious tapestry of beliefs and assumptions that defines who we are as human beings, what we think the world is like, and how we and the world interact". ${ }^{46}$

43 Michaels, F.S. Monoculture: How One Story is Changing Everything. Canada: Red Clover Press, 2011.

44 Michaels, op. cit., p. 4.

45 Michaels, op. cit., p 6.

46 Michaels, op. cit., p. 14. 
The concept of monoculture can be used to describe the persistent attitudes of adjudicators, such as preference for limited review. Arold, Groussot and Petursson have conducted interviews with judges from the CJEU which indicate that two elements contribute to the creation and maintenance of a legal monoculture within the CJEU: socialization of new judges and lack of dissenting opinions. ${ }^{47}$ The idea of calling the CJEU a 'family' has been developed early on and the socialization of new judges was an important part of this process. One of their interviewees described this process:

There was a culture at the Court of developing good social relations between the members of the Court by social means. An incoming judge was invited during a year by his/her colleagues. This helped to form a good professional functioning of the Court. Because, if you know your colleagues better, you know more about their personal backgrounds and family backgrounds, and then it might be easier to discuss issues. ${ }^{48}$

Since there is no in-house training, judges learn with and from their colleagues the practical aspects of the procedure. Since, the stability of the system and coherence of the case-law are important, "newcomers are not expected to change things" and "are not advised, in a collegiate court, to pursue individual ideological goals". 49

The second element that contributes to the creation of a monoculture within the European judicature is the collegiate nature of the court, with its corollary principle - lack of dissenting opinion. The judges that Arold, Groussot and Petursson interviewed described the adjudication process as a team-work whereby "we come together and then you see what is common in our thinking and you see that there is a lot that is in common although the approaches are different, but you see at the end that we are able to come to a common solution". 50

As Arold, Groussot and Petursson acknowledge, "in this atmosphere of communality, a strong individualistic view would irritate". ${ }^{51}$ As a result, consensus is the preferred option and judges prefer to make concessions in order to reach consensus instead of pursuing majority voting. When consensus cannot be reached, voting takes place in reverse order of seniority to avoid that new

47 Arold Lorenz, Groussot and Petursson, op. cit.

48 Arold Lorenz, Groussot and Petursson, op. cit., p 29.

49 Arold Lorenz, Groussot and Petursson, op. cit., p. 3o.

$5^{\circ} \quad$ Arold Lorenz, Groussot and Petursson, op. cit., p. 31 .

51 Arold Lorenz, Groussot and Petursson, op. cit. 
judges are influenced by the votes of senior judges..$^{52}$ Finally, in relation to the type of disputes that lead to majority voting, the judges that Arold, Groussot and Petursson interviewed noted that all cases - raising human rights issues, but also very technical matters - can result in strong discussions on the bench. The CJEU judges also noted that "if a question requires specific technical knowledge it can also be quite difficult to arrive at a legal solution". ${ }^{3}$

\subsection{Adjudication and Problems of Organized Complexity}

"Science and engineering have been unable to keep pace with the second order effects produced by their first order victories".

Gerald Weinberg

In a paper published in 1948, Warren Weaver argued that there were three types of problems that science was called to solve. ${ }^{54}$ The first type were the problems of simplicity characteristic of the seventeenth, eighteenth and nineteenth centuries which dealt with problems having one or two variables.

Starting with 1900, "physical sciences developed an attack on nature of an essentially and dramatically new kind", developing analytical methods which could deal with two billion variables. Thus, techniques of probability theory and of statistical mechanism offered an opportunity to the scientific community to deal with what Weaver calls problems of disorganized complexity. ${ }^{55}$ Problems of disorganized complexity are those in which "the number of variables is very large, and one in which each of the many variables has a behaviour which is individually erratic, or perhaps totally unknown. However, in spite of this helter-skelter, or unknown, behaviour of all the individual variables, the system as a whole possesses certain orderly and analysable average properties". ${ }^{56}$

Weaver argued that in the space between problems with two variables and problems with two billion variables lies a middle region whose prime characteristic is not the number of variables involved in the scientific phenomenon. Weaver argued that "the really important characteristic of the problems of this middle region, which science has as yet little explored or conquered, lies in

52 Arold Lorenz, Groussot and Petursson, op. cit., p. 32.

53 Arold Lorenz, Groussot and Petursson, op. cit., p. 151.

54 Weaver, Warren. "Science and Complexity." American Scientist 36 (1948): pp. 536-544.

55 Weaver, op. cit., p. 538.

56 Weaver, op. cit., p. 539 . 
the fact that these problems, as contrasted with the disorganized situations with which statistics can cope, show the essential feature of organization". 57 In other words, these are problems of organized complexity, which can answer challenges in the biological, medical, but also psychological, economic and political sciences.

Weaver highlighted that "science must (...) learn to deal with these problems of organized complexity" ${ }^{58} \mathrm{He}$ predicted that three developments could contribute to this. First, quantitative experimental methods and mathematical analytical methods used in the physical sciences are embraced by the biological, the medical and the social sciences. Second, the new types of electronic computing devices developed during wartime could be used for scientific research as well. Finally, Weaver places emphasis on another wartime development, the use of mixed-teams approach to operations analysis. Initiated by the British Army during the wwII's most complex anti-submarine and air campaigns, Weaver praised the wisdom of the mixed teams composed of engineers and physicists, but also psychologists, biochemists, endocrinologists and specialists from other social sciences. ${ }^{59}$

The theory developed by Weaver in his 1948 paper can shed light on the topic of the current book in two ways. On the one hand, the legal questions that EU courts are called to answer in EU competition law cases concern problems of organized complexity. The functioning of markets and the behaviour of economic agents on the market concern a large number of variables that are, however, operating as a whole. On the other hand, one could argue that the EU Courts' deferential judicial review is justified by the fact that the EU Commission is better placed to deal with problems of organized complexity. The CJEU employs lawyers and interpreters. The EU Commission, on the other hand, recruits both generalists and specialists from a wide pool of applicants that are trained throughout their career. This can lead, as Weaver envisioned, to mixed, multi-disciplinary teams which are better placed to tackle problems of organized complexity.

I have offered in Part 4 of the current book to test whether the judicial review performed by the CJEU in EU competition law is compatible with the right to a fair trial enshrined in Article 6(1) ECHR. For this, Chapter 14 described

\footnotetext{
57 Weaver, op. cit., p. 540.

58 Weaver, op. cit., p. 541.

59 Weaver, op. cit., p. 541.
} 
the case-law of the ECtHR concerning the right to an effective judicial remedy. Chapter 15 argued that the ECtHR distinguished between three situations requiring three types of judicial review depending on the type of administrative discretion exercised.

First, Section 15.1. showed that when administrative discretion was exercised in polycentric issues, the review of legality did not breach the right to a fair trial. In these instances, the administrative discretion concerned wide policy matters and was in fact the expression of the electorate's will.

Second, Section 15.2. showed that when administrative discretion concerned monocentric issue, only full judicial review was compatible with the right to a fair trial. Such judicial review performed a quality control function over the administrative branch.

Third, Section 15.3. argued that when administrative discretion was exercised as policing powers, only full judicial review was acceptable in a democratic society.

Turning to EU competition law then, Chapter 16 showed that, despite the entry into force of the Charter and the wide interpretation offered by the CJEU to the right to an effective remedy in various fields of law, the CJEU maintained their deferential judicial review in EU competition law.

Chapter 17 was devoted to analysing the reasons for which the CJEU prefers judicial deference to EU Commission's practice in competition law. It was suggested that the privileged place occupied by economics within social sciences, the distinction between the economic man and the administrative man, biases, monoculture and the problems of organized complexity can clarify this preference.

To conclude, I must first observe, as it has been shown in particular in Chapters 11 to 13 above, that the EU Commission is exercising not only a wide discretion when enforcing EU competition law. The EU Commission exercises policing powers by investigating, searching, seizing and interrogating. Also, the EU Commission has largely interpreted the breadth of its own powers. It must then follow that the judicial review applied by the CJEU should be full and constant. However, the combined effect of, on the one hand, Articles 261 and $263 \mathrm{TFEU}$ and, on the other hand, the interpretation of these provisions by the CJEU, is that the CJEU continues to apply a limited judicial review of competition law decisions. Therefore, I suggest that such review is incompatible with the right to a fair trial enshrined in Article 6(1) ECHR. 